\title{
Mechanism of coordinated access to orphan drugs
}

\author{
R DeRidder", C Adriaens, D Kleinermans, M Mortier, A Quanten, F Arickx \\ From 6th European Conference on Rare Diseases and Orphan Products \\ Brussels, Belgium. 23-25 May 2012
}

\section{Context}

Although the EU Council stated[1] that "All health systems in the EU aim to make provision, which is patient-centered and responsive to individual need", numerous sources show important and unacceptable differences in access to orphan drugs in the Member States of the European Union (EU COM [2], EURORDIS [3,4], BE EU Presidency $[5,8]$, EU Council [6]). With this regard, in the context of the 2010 Belgian EU presidency initiative on 'Innovation and Solidarity' and within the framework of the process on corporate responsibility in the field of pharmaceuticals [7], EU Commissioner Tajani launched the project Mechanism of Coordinated Access to Orphan Drugs.

\section{Objectives}

Design a concrete operational mechanism of coordinated access to orphan drugs for patients, stakeholders and Member States. Through coordination and cooperation between stakeholders and Member States at EU level, real access is to be provided to orphan medicinal products for patients with unmet medical needs and for whom these solutions would otherwise be out of reach - in an affordable and sustainable way ("real life access").

\section{Methodology}

The project is managed by Belgium(NIHDI), supported by the European Commission (ENTR, SANCO, COMP, MARKET) and Eminet. Thirteen other Member States (Austria, Estonia, Finland, France, Greece, Hungary, Italy, Malta, Netherlands, Poland, Portugal, Spain, Sweden) are participating, together with the different stakeholders (AIM, EPF, ESIP, EURORDIS, CPME, EFPIA, EGA, EuropaBio, GIRP). Three Work packages (WP) cover the three different aspects of granting effective access to medicines (WP1: Identifying and assessing a relevant orphan drug, WP2: Selection of the target population and mechanisms of funding, WP3: Treatment ). In each WP operational steps and implementing activities were identified. Feasibility at present and opportunities for near future development of desirable coordinated activities were studied, and no-go solutions were documented and rejected. Integrating the three WP will lead to the development of implementable scenarios for pilot projects and result in policy recommendations.

\section{Discussion}

Guaranteeing an added value for all stakeholders and especially from a patient's perspective through cooperation and coordination is the main objective of the project. Although coordinated access at an European level will be organised on a voluntary basis, at some point in time, some sort of commitment from the participating partners is required. Moreover, it is crucial that the subsidiarity principle is not compromised in any way. Duplication of efforts will be avoided and previously made investments - in terms of financial and human resources, expertise and experience (ex. by EUnet HTA, EMA COMP, EUCERD, CAVOD) will be valorised.

Published: 22 November 2012

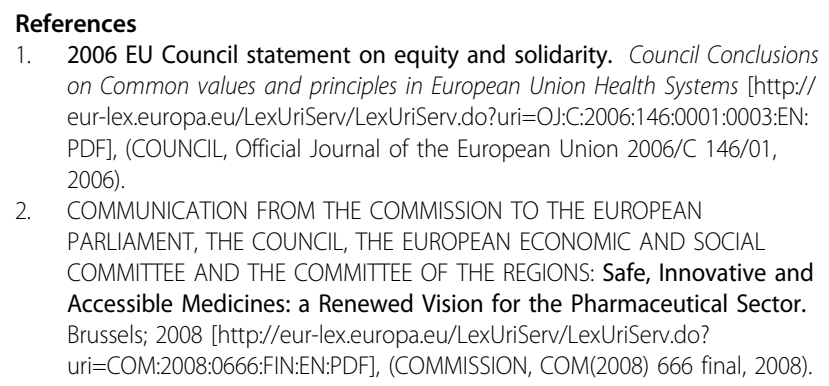

1. 2006 EU Council statement on equity and solidarity. Council Conclusions on Common values and principles in European Union Health Systems [http:// eur-lex.europa.eu/LexUriServ/LexUriServ.do?uri=OJ:C:2006:146:0001:0003:EN: PDF], (COUNCIL, Official Journal of the European Union 2006/C 146/01, 2006).

2. COMMUNICATION FROM THE COMMISSION TO THE EUROPEAN PARLIAMENT, THE COUNCIL, THE EUROPEAN ECONOMIC AND SOCIAL COMMITTEE AND THE COMMITTEE OF THE REGIONS: Safe, Innovative and Accessible Medicines: a Renewed Vision for the Pharmaceutical Sector. Brussels; 2008 [http://eur-lex.europa.eu/LexUriServ/LexUriServ.do? uri=COM:2008:0666:FIN:EN:PDF], (COMMISSION, COM(2008) 666 final, 2008). 
3. Fabrizia BIGNAMI, P E: EURORDIS SURVEY ON ORPHAN DRUGS: AVAILABILITY IN EUROPE. 2007, Retrieved from EURORDIS: http://www. eurordis.org/IMG/pdf/2007ODsurvey-eurordis.pdf.

4. 5th EURORDIS Survey On Access To Orphan Drugs In Europe Survey. [http://img.eurordis.org/newsletter/pdf/mar-2011/ERTC_13122010_YLeCam_ Final.pdf].

5. BE EU Council Presidency: Background report for the ministerial conference 'Innovation and solidarity on pharmaceuticals'. A call to make valuable innovative medicines available in the European Union. 2010 [http://www.inami.be/information/all/studies/study-20100923-24/pdf/ background_report_en.pdf].

6. EU Council Conclusions on Innovation and Solidarity in Pharmaceuticals. 2010 [http://www.consilium.europa.eu/uedocs/cms_Data/docs/pressdata/ en/lsa/118278.pdf].

7. Process on Corporate Responsibility in the field of Pharmaceuticals. [http://ec.europa.eu/enterprise/sectors/healthcare/competitiveness/ process_on_corporate_responsibility/index_en.htm].

8. Picavet $E$, et al: Market uptake of orphan drugs - a European analysis. J Clin Pharm Ther 2012.

9. Eminet:[http://www.goeg.at/en/Area/Pharma-economics.html].

10. EUCERD (European Union Committee of Experts on Rare Diseases): [http:// www.eucerd.eu/].

doi:10.1186/1750-1172-7-S2-A24

Cite this article as: DeRidder et al:: Mechanism of coordinated access to orphan drugs. Orphanet Journal of Rare Diseases 2012 7(Suppl 2):A24.

\section{Submit your next manuscript to BioMed Central} and take full advantage of:

- Convenient online submission

- Thorough peer review

- No space constraints or color figure charges

- Immediate publication on acceptance

- Inclusion in PubMed, CAS, Scopus and Google Scholar

- Research which is freely available for redistribution

Submit your manuscript at www.biomedcentral.com/submit 